\title{
Socio-economic status and the duration of pulmonary tuberculosis symptoms in women treated at the Mazovian Treatment Centre of Tuberculosis and Lung Diseases in Otwock
}

\author{
Status społeczno-ekonomiczny i czas trwania objawów u kobiet chorych na gruźlicę \\ płuc leczonych w Mazowieckim Centrum Leczenia Chorób Płuc i Gruźlicy w Otwocku \\ The Authors declare no financial disclosure
}

Abstract

Introduction: The prevalence of tuberculosis depends on various factors such as migration, homelessness, malnutrition, unemployment, bad life conditions and the aging of a society. The aim of this study was to evaluate tuberculosis in females treated at the Mazovian Treatment Centre of Tuberculosis and Lung Diseases (Mazowieckie Centrum Leczenia Chorób Płuc i Gruźlicy) in Otwock, regarding the context of demographic, social and professional status of female patients. The duration of the illness and the extent of radiographic changes were also taken into consideration.

Material and methods: The study was carried out retrospectively. The medical documentation that was evaluated concerned 100 women, aged between 20 and 92, hospitalized at the Mazovian Treatment Centre of Tuberculosis and Lung Diseases in Otwock in the years 2005 and 2006 due to bacteriologically confirmed tuberculosis.

Results: Most women with tuberculosis lived in cities (65\%), 32\% of the evaluated patients lived in villages and $3 \%$ were homeless. $1 / 3$ of females were under 40 years of age, and $1 / 3$ were over 60 years of age. Only $29 \%$ of the women were professionally active and $25 \%$ were unemployed. $60 \%$ of women were not married. $35 \%$ of women with tuberculosis were bringing up children and $7 \%$ had abandoned their offspring. More than $1 / 3$ of women had had tuberculosis symptoms for more than half a year before tuberculosis was diagnosed. $40 \%$ of women with tuberculosis had small radiological changes (1 to 2 lung fields); however, $26 \%$ of them had extensive changes covering 4 to 6 lung fields.

Conclusions: The majority of women with tuberculosis in the Mazovian district are single, over 40 years old, unemployed inhabitants of cities. $30 \%$ of women in the study group had had symptoms for more than 6 months before tuberculosis was diagnosed. $40 \%$ of women with tuberculosis had very extensive radiological changes covering 4 to 6 lung fields.

Key words: tuberculosis, women, epidemiology, social and economic factors

Pneumonol. Alergol. Pol. 2014; 81: 3-9

\section{Streszczenie}

Wstęp: Chorobowość na gruźlicę zależy od czynników społeczno-ekonomicznych, takich jak migracje ludności, bezdomność, niedożywienie, bezrobocie, złe warunki bytowe, starzenie się społeczeństw. Celem pracy była ocena występowania gruźlicy u kobiet leczonych w Mazowieckim Centrum Leczenia Chorób Płuc i Gruźlicy w Otwocku (MCLChPiG) z określeniem statusu demograficznego, zawodowego i społecznego oraz z oceną czasu trwania choroby i rozległości zmian radiologicznych.

Materiał i metody: Praca miała charakter retrospektywny. Oceniono dokumentację medyczną 100 kobiet w wieku 20-92 lat, hospitalizowanych w MCLChPiG w latach 2005-2006 z powodu potwierdzonej bakteriologicznie gruźlicy płuc.

Address for correspondence: Maria Błachnio, MD, Mazovian Treatment Centre of Tuberculosis and Lung Diseases in Otwock, ul. Narutowicza 80, 05-400 0twock,

tel.: +482234464 71, e-mail: sekretariat.otw@otwock-szpital.pl

10.5603/PiAP.2014.0002

Praca wpłynęła do Redakcji: 27.05.2013 r.

Copyright (C) 2014 PTChP

ISSN 0867-7077 


\begin{abstract}
Wyniki: Większość kobiet chorych na gruźlicę mieszkała w miastach (65\%), podczas gdy ze wsi pochodziło 32\%, a 3\% stanowiły osoby bezdomne. Wśród badanych kobiet $1 / 3$ nie przekroczyła 40 . rż., a $1 / 3$ ukończyła 60 . rż. Tylko $29 \%$ chorych kobiet było czynnych zawodowo, a $25 \%$ stanowiły kobiety bezrobotne. W badanej grupie $60 \%$ kobiet było niezamężnych. Opiekę nad dziećmi sprawowało jedynie 35\% chorych na gruźlicę kobiet, a 7\% porzuciło swoje dzieci. Czas trwania objawów klinicznych do chwili rozpoznania choroby wahał się od zera, gdy zmiany radiologiczne wykryto przypadkowo u osób bezobjawowych, aż do dwóch lat. U ponad 1/3 chorych kobiet objawy gruźlicy trwały ponad pół roku. Niewielkie zmiany radiologiczne obejmujące 1-2 pola płucne obserwowano u 40\% chorych, natomiast u 26\% stwierdzono rozległe zmiany obejmujące 5-6 pól płucnych.

Wnioski: Większość prątkujących kobiet na Mazowszu to osoby samotne, niepracujące zawodowo mieszkanki dużych miast, które ukończyły 40. rż. Objawy kliniczne występowały u 30\% z nich ponad pół roku przed ustaleniem rozpoznania, a u 40\% zmiany radiologiczne były bardzo rozległe obejmujące 4-6 pól płucnych.
\end{abstract}

Słowa kluczowe: gruźlica, kobiety, epidemiologia, czynniki społeczno-ekonomiczne

Pneumonol. Alergol. Pol. 2014; 81: 3-9

\section{Introduction}

Despite the introduction of effective antituberculosis drugs, tuberculosis (TB) is still a serious health problem and one of the most significant causes of death. The World Health Organization estimates that each year 9 million new tuberculosis cases occur and 1.7 million people die from this disease [1]. The prevalence of TB reaches 10/100,000 in West European countries, over 150/100,000 in Asian countries, and more than 300/100,000 in African countries [1]. In Poland, the epidemiology figures show a constant improvement; however, in 2011, the prevalence of tuberculosis still exceeded 20/100,000 [2].

The prevalence of TB is connected with numerous socio-economic factors such as: overpopulation, migration, homelessness, unemployment, malnutrition and famine [3]. In the second half of the $19^{\text {th }}$ century the epicentre of TB was located in Western Europe. It was connected with rapid industrialization that led to overpopulation of cities and bad sanitary conditions in the workplace and place of residence. At that time, tuberculosis was rarely diagnosed in Africa. In the $20^{\text {th }}$ century a TB epidemic was spreading from the northwest towards the southeast. The epidemiological situation in Europe had improved long before the introduction of antituberculosis drugs. It is considered that it was caused by improvements in standard of living, nutrition and living conditions, shortening of working hours, longer rest, the introduction of systems of disease detection, isolation of patients, secondary prevention, i.e. prevention of the consequences of the disease by its early detection (screening examination), rapid introduction of treatment, and specialized therapeutic and preventive institutions.

In West European countries, the highest incidence of TB is still observed in large urban areas compared to small towns, which is partly connected with centres of immigrants who often live in the suburbs of big cities. Nearly half of new TB cases in France are diagnosed in the small Paris region, where the TB incidence is five times higher than the mean incidence for the country [4]. In Poland, no significant differences in TB incidence are observed between the urban and rural population [2]. In the countries with the highest epidemic figures, TB affects mainly young people and those who work professionally [5]. Along with the improvement of the epidemiological situation, the disease occurs in older patients. In Poland more than 10 years ago elderly patients with TB (over 65 years of age) accounted for $1 / 5$ of all TB cases, and currently they constitute nearly 1/3 [2]. Generally, men suffer more often from TB than women do [3, 6]. In Poland women account for $1 / 3$ of TB patients (the incidence rate for women is $13.6 / 100,000$ whereas for men it is $30.1 / 100,000$ ) [2]. In the past the difference was not so big; in the 1930s women accounted for $44 \%$ of patients who died from tuberculosis [7]. The differences between TB incidence in men and women are increasing with age. In children or adolescents no differences are observed between the incidence rate in boys and girls [2]. Starting with the $21^{\text {st }}$ year of life the difference between the number of TB cases in men and women is growing rapidly, and it reaches its peak in the 50-59 years age group, at which point the TB incidence rate in women is nearly four times lower [2]. In other countries these differences are not so distinct. In France, the incidence rate in men is $13 / 100,000$, and in women it is $8 / 100,000$ [8]. The mean proportion of men to women among TB patients worldwide is 1.96 [9]. In some countries it reaches 3, and in Armenia even 4.7 [10]. The causes of such differences are not fully known, but it is presumed that it is connected with socio-economic and cultural factors [11], as well as hormonal [10] and genetic factors [12]. 
In Poland, during the last 20 years significant socio-economic and demographic changes have been taking place. These processes have influenced the epidemiological situation of tuberculosis. Although the incidence of TB has undoubtedly decreased, it is vital to determine who suffers from the disease, as it will allow suitable programs to be formulated for monitoring the situation in high-risk groups. The aim of the study was to evaluate the prevalence of TB in women treated at the Mazovian Treatment Centre of Tuberculosis and Lung Diseases in Otwock, to determine their demographic, social and professional status, and to assess the duration of the disease and the extent of radiological changes.

\section{Material and methods}

The study was retrospectively designed. The medical documentation of 100 female patients with bacteriologically confirmed pulmonary tuberculosis was reviewed. Due to the disease, the patients were hospitalized at the Mazovian Treatment Centre of Tuberculosis and Lung Diseases in Otwock in the period from June 2005 to March 2006. The following factors were taken into account: age, place of residence, professional activity, duration of symptoms before diagnosis of the disease, and the extent of radiological changes. Depending on the place of residence, the patients were divided into those who live in cities and those who live in the countryside, we also distinguished the group of homeless patients. Marital status was classified as: married, unmarried, divorced or widow. In respect of professional activity the following categories were distinguished: professionally active, retirees or pensioners, unemployed or maintained by husband. The duration of symptoms was determined based on the patient's history taken during admission to hospital. The extent of radiological changes was assessed depending on the number of affected lung fields, with each lung being divided into three fields (upper, medium and lower). All the examined women lived in Mazowsze.

\section{Results}

The mean age of the examined women was 52 years. The youngest patient was 20 years of age and the oldest was 92. In the study group, young patients ( $<40$ years) accounted for $33 \%$. The groups of patients at the age of $>60$ years and between 40 and 60 years were similarly large (Fig. 1). Most patients (65\%) lived in cities, whereas $32 \%$ of women lived in the countryside (Fig. 2). 3\% among TB

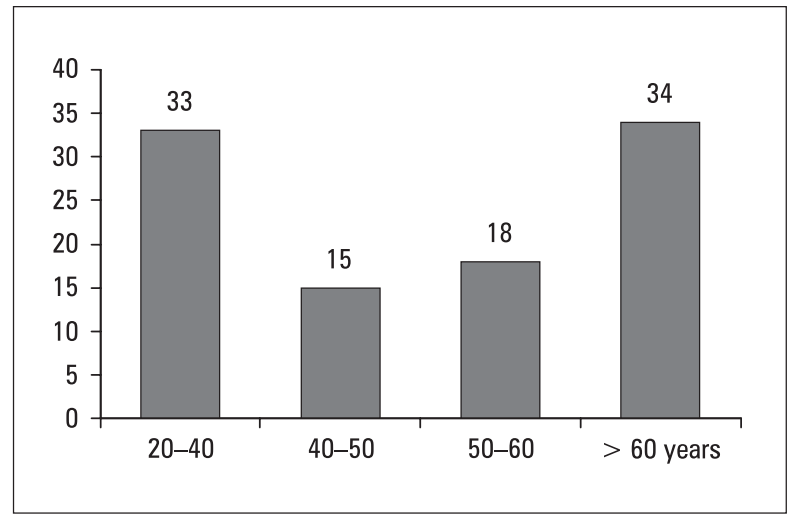

Figure 1. The age of examined patients

Rycina 1. Struktura wiekowa badanych chorych

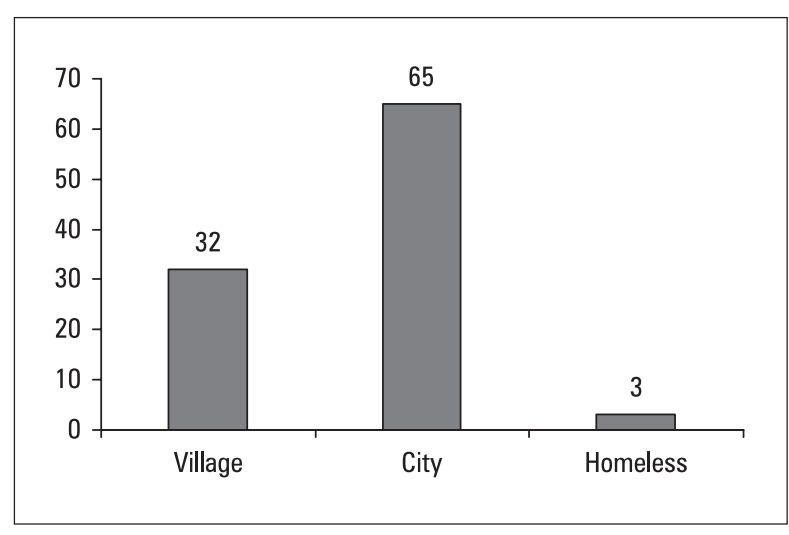

Figure 2. Patients' place of residence

Rycina 2. Miejsce zamieszkania pacjentek

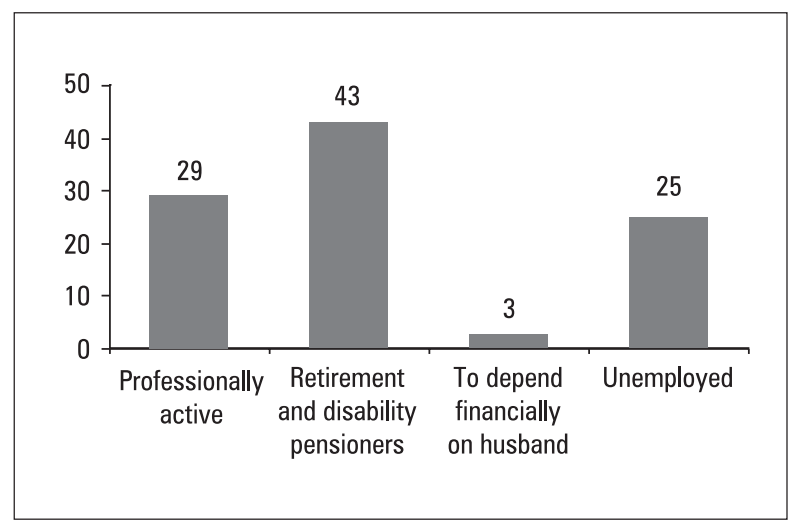

Figure 3. Employment status of examined women

Rycina 3. Status zawodowy badanych kobiet

patients were homeless. Only 29\% of women with TB were professionally active, and $25 \%$ of subjects were unemployed (Fig. 3). The most numerous group (43\%) included retirees and pensioners. Only $3 \%$ of women declared to be maintained by their husband. As many as $60 \%$ of women lived 


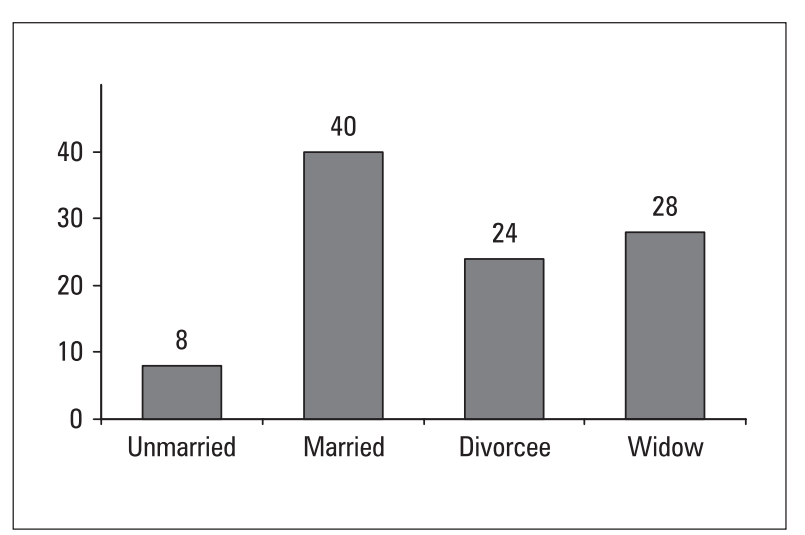

Figure 4. Marital status of examined women

Rycina 4. Stan cywilny badanych kobiet

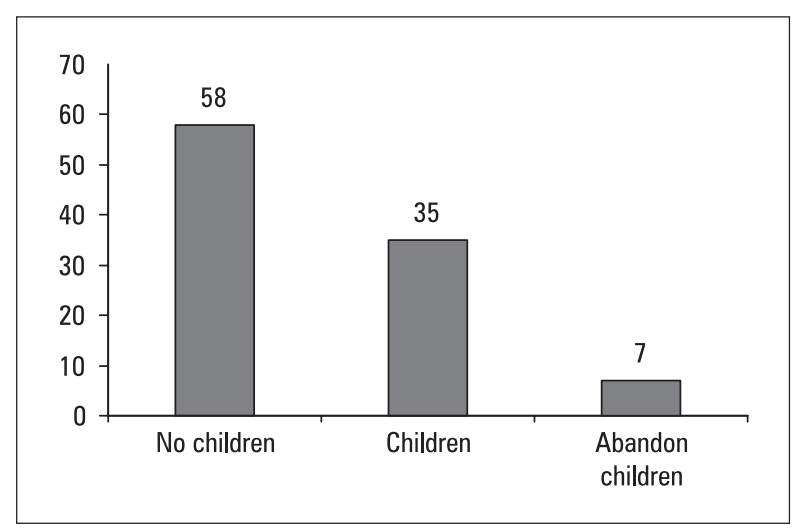

Figure 5. Care of the children

Rycina 5. Opieka nad dziećmi alone (Fig. 4). Most of them were widows (28\%) and divorcees (24\%); unmarried women accounted only for $8 \%$. 35\% among sputum-positive patients were taking care of children under 14 years of age (Fig. 5). At the moment of diagnosis, most of the patients (58\%) were not taking care of children, and $7 \%$ of the studied women had abandoned their own children in the past.

The duration of symptoms of the disease until diagnosis fluctuated from zero, when radiological changes were detected incidentally in patients with no symptoms, up to 2 years (Fig. 6). 7\% of patients did not report any ailments at the moment of diagnosis, but $13 \%$ of the studied women had TB symptoms for more than one year. $33 \%$ of patients were diagnosed within three months from the appearance of symptoms, but as many as $43 \%$ of patients had symptoms from 3 to 12 months. Small radiological changes including 1-2 lung fields were observed in $40 \%$ of patients, while in $26 \%$ of the studied women extensive changes, which included 5-6 lung fields, were found (Fig. 7). In all the women the diagnosis of pulmonary tuberculosis was confirmed bacteriologically in the culture from sputum. Acid-fast mycobacteria in smears were found in nearly half of them (49\%) before admission to the Mazovian Treatment Centre of Tuberculosis and Lung Diseases, and a positive result in PCR was obtained in 1\% of patients before hospitalization. Recurrence of

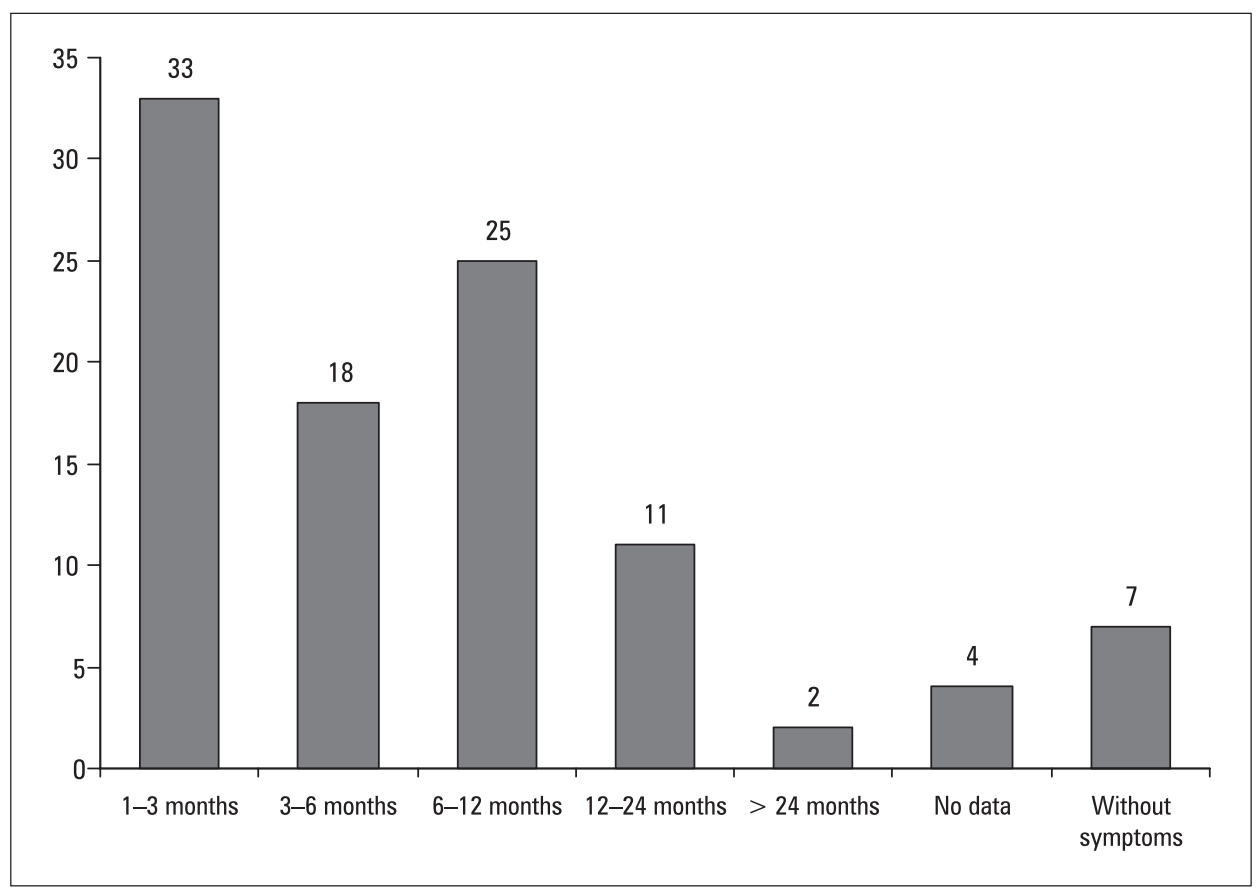

Figure 6. The duration of the symptoms of TB

Rycina 6. Czas trwania objawów chorobowych 


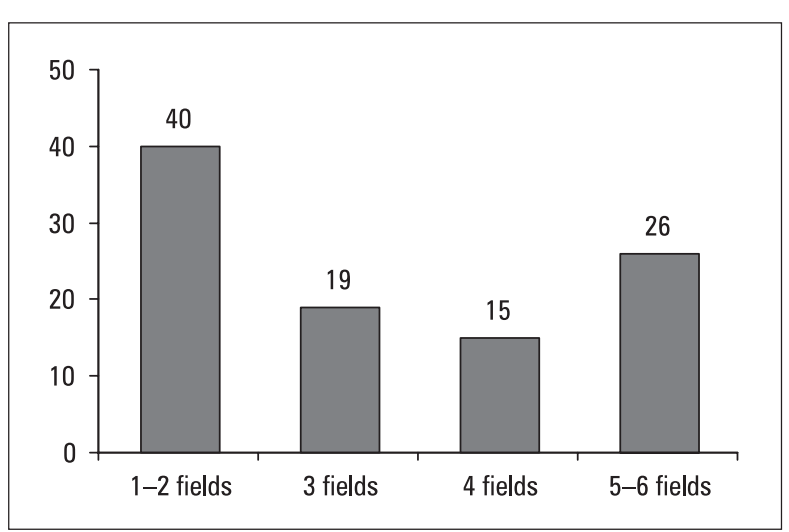

Figure 7. Distribution of radiological pulmonary changes

Rycina 7. Rozlegtość zmian radiologicznych w płucach

TB was diagnosed in 18\% of patients, including $2 \%$ of women who had a third recurrence (i.e. they suffered from TB for the forth time). None of the women included in the study was diagnosed with concomitant HIV infection. No cases of extrapulmonary tuberculosis were found in the study group.

\section{Discussion}

The presented results reflect correctly the situation in the region because the Mazovian Treatment Centre of Tuberculosis and Lung Diseases in Otwock is the only centre in Mazowsze that has signed a contract for the treatment of tuberculosis with the National Health Fund (NFZ). The role of socio-economic factors in the prevalence of TB is often emphasized [13]. The obtained results show that in Mazowsze, bacteriologically confirmed TB occurs mainly in unmarried women who do not have children, do not work, live in cities and who are middle-aged. A similar evaluation of TB patients was made by Rydzewska et al. [14] in the population of inhabitants of Kalisz in the years 1991-2000. Also in Kalisz, only 35\% of women with TB had permanent work, and the majority of them were manual workers [14]. Before system transformation in 1989, unquestionably more TB patients were professionally active. In the Lublin region in the years 1988-1992, the proportion of employed people among TB patients was twice as high [15], and in 1979 in Lublin it was three times higher [16] than in the present paper. In comparison with the study conducted in Kalisz, 10 years later in Mazowsze, there was a higher proportion of unemployed women (25\% vs. $16 \%$ ). The percentage of TB women receiving retirement, pension or social allowance was similar in Kalisz (44\%) [14] and in the study group in
Mazowsze (43\%). The proportion of women who were maintained by their husband in Kalisz was $4.5 \%$, in Mazowsze it was 3\% [14]. As many as $3 \%$ of sputum-positive patients in Mazowsze were homeless, whereas at the end of the previous century such cases were not observed. Similarly, earlier studies conducted among homeless people in Wielkopolska have not shown a single case of TB in women [17]. At the beginning of the socio-economic changes in 1992, the proportion of homeless patients among men and women with tuberculosis was merely 1\% [18]. Among men treated in Otwock, homeless patients accounted for $10 \%$ of cases with bacteriologically confirmed TB [19]. It is crucial for the results of treatment because treatment failure is observed in a high proportion of homeless patients with no resources to live on [18].

$2 / 3$ of women with TB in Mazowsze lived in cities, whereas only $32 \%$ lived in the countryside. Among TB patients who were examined in 1959 in the Lublin region, the number of patients who lived in cities and in the countryside was comparable [20]. This may be caused by the demographic changes that took place in Poland over the last few decades. On the one hand the number of rural inhabitants has decreased, on the other hand their access to medical care has improved. Before the Second World War Prof. M. Kacprzak drew attention to the fact that the epidemiological situation was known only in cities, whereas in the countryside it was unspecified [7]. The availability of medical care in the past was very limited. Before the Second World War in eastern rural regions of the Republic of Poland, only 42 hospital beds were registered for tuberculosis patients, whereas in western regions this figure was 964 [7].

The proportion of married women among female TB patients in Kalisz was 48\% [14], slightly higher than that shown in the present study $(40 \%)$. The obtained results suggest that widowhood and divorce are factors that increase the risk of TB incidence [21]. To confirm this observation, it is recommended that a study on a larger group of subjects be carried out. Husbands and children of sputum-positive women are at high risk of TB incidence [14, 22]. In the study group, women over 50 years of age accounted for almost 50\%, while before the Second World War they accounted for only 17\% [7]. Among female TB patients who were examined in 1957, the vast majority were under 50 years of age [20]. Currently, the age of women with TB is different from that observed in the past, when the peak of incidence occurred at 20-24 age of years [23]. 
This observation has been confirmed by recently conducted studies in Poland [24].

In 1957 the mean duration of symptoms until diagnosis in women was 7 months in the countryside and 5 months in cities [22]. Although during the last 50 years the availability of medical care in Poland has significantly improved and people are more aware of health problems, particularly in rural environments, only $33 \%$ of patients from the study group have reported the occurrence of symptoms within a period shorter than 3 months, whereas in $38 \%$ of patients the symptoms had lasted more than 6 months. The presented results show how important appropriate education of patients is. It should include patients who come to see a doctor due to different reasons. The problem is particularly vital due to the abandonment of active model of looking for TB and screening examinations, with the focus on diagnosis of people with symptoms of the disease. Therefore, the patient must know what symptoms should alarm him/her and when he/she should see a doctor. It may be worth preparing some educational material that would be available in outpatient clinics to remind patients of tuberculosis, its symptoms, transmission of infection and the ways of detecting the disease. Nevertheless, physicians should know the rules of diagnosis of TB, and they should be constantly alert, because, as was confirmed by the present study, tuberculosis is still common in Polish society.

The extent of changes in the lungs in the study group in TB patients was very close to the results obtained in a large group over 40 years ago [20]. In the study of 1957 in the population of men and women in the Lublin region, changes limited to $1-2$ fields were found in $45.5 \%$ of patients, 3 fields were affected in 14\%, 4 fields - in $12 \%$ and $5-6$ fields - in $27.5 \%$ of patients [20]. In women, changes including only $1-2$ fields were observed in the past in 53\% of patients [20], whereas currently very extensive radiological changes including 4-6 lung fields have been found in 40\% of patients. So it seems that there is no improvement of early detection of tuberculosis. Clearly, better availability of medical care is not combined with early detection of TB. One of the socio-economic factors connected with TB incidence that had great significance in the past was the level of education which determined the standard of living, the prevalence of fibrous-cavernous TB and the proportion of failure [20].

In central eastern European countries, socio-economic factors also play a crucial role in the development of tuberculosis. In Estonia, the factors that predispose to TB are: unmarried marital status, poor education, unemployment and homelessness [25]; in Russia they are lack of work and resources to live on, living in overcrowded flats and staying in prison [26]. In non-European countries, different social and demographic factors influence the prevalence of TB and failure of treatment. In Mexico, living in the country, working in agriculture, poor education and age over 45 years contribute to death due to TB [27]. In Indonesia, TB incidence is connected with malnutrition, low BMI, unemployment and living in large families [28]. Factors that play a significant role in the incidence of TB are: race, overpopulation, poverty, lack of work or insurance, low income and poor education [29].

In all regions of the world tuberculosis occurs more frequently in men than in women (on average $1.9 \pm 0.6$ ) [9]. Cultural, social and demographic factors in developing countries have led to the hypothesis that limited availability of medical care may underestimate TB incidence in women [9]. A meta-analysis conducted on nearly 30 reports has not confirmed this theory [30]. There may be some biological mechanisms that cause different incidence of TB in men and in women. Sex hormones, genetic diseases connected with sex and types of regulation of metabolism may also determine the incidence of infectious diseases, but there is no evidence that it concerns tuberculosis. Oestrogens influence the production of interferon gamma that may contribute to the observed differences in the incidence of TB [31]. It has been shown that other infections of the respiratory system occur more frequently in men than in women [32]. Legionnaire's disease occurs four times more often in men than in women [33]. Many studies suggest that TB susceptibility depends on sex [9, 30]. Among the factors that may influence the observed differences in TB incidence among men and women are the following: the prevalence of smoking cigarettes, alcoholism and the type of practiced profession etc.

The presented results show demographic changes in the population of female TB patients in Poland. The majority of women hospitalized due to tuberculosis in Mazowsze were unemployed, non-cohabiting residents of a city, over 40 years of age. In some of them the symptoms of the disease have manifested for over half a year, and radiological changes of the lungs have been extensive. This points out poor awareness or insufficient availability of medical care, and shows the high-risk groups that need more intense activities aimed at early detection of tuberculosis. 


\section{Conflict of interest}

\section{The Authors declare no conflict of interest.}

\section{References:}

1. WHO Report. Global Tuberculosis Control. Surveillance planning financing. WHO Press Geneva 2008.

2. Korzeniewska-Koseła M. (red.). Gruźlica i choroby układu oddechowego w Polsce w 2011 roku. Instytut Gruźlicy i Chorób Płuc w Warszawie 2012.

3. Murray J.F. La tuberculose dans le monde: situation et perspective en l'an 2001. Rev. Mal. Respir. 2001; 18: 479-483.

4. Che D., Cailhol J., Campese C. i wsp. Situation epidemiologique de la tuberculose en Ile-de-France en 2001. Rev. Mal. Respir. 2004; 21: 272-278.

5. Pardeshi G. Survival analysis and risk factors for death in tuberculosis patients on directly observed treatment-short course. Indian J. Med. Sci. 2009; 63: 180-186.

6. Bhat J., Rao V.G., Gopi P.G. i wsp. Prevalence of pulmonary tuberculosis among the tribal population of Madhya Pradesh, central India. Int. J. Epidemiol. 2009; 38: 1026-1032.

7. Kacprzak M. Gruźlica w miastach polskich z ludnością powyżej 100 tysięcy. Druk. Kop. Prac. Warszawa 1932.

8. Bouvet E. Epidemiologie de la tuberculose. Prevention et prise en charge de la tuberculose en France. Rev. Mal. Respir. 2003; 20: 7S13-7S19.

9. Neyrolles O., Quintana-Murci L. Sexual inequality in tuberculosis. PLoS. Med. 2009; 6: e1000199.

10. WHO. Global tuberculosis control 2009: epidemiology, strategy, financing. Geneva: WHO. 2009. Available: http://www.who. int/tb/country/en/index.html.

11. Weiss M.G., Sommerfeld J., Uplekar M.W. Social and cultural dimensions of gender and tuberculosis. Int. J. Tuberc. Lung Dis. 2008; 12: 829-830.

12. Baghdadi J.E., Orlova M., Alter A. i wsp. An autosomal dominant major gene confers predisposition to pulmonary tuberculosis in adults. J. Exp. Med. 2006; 203: 1679-1684.

13. Tignor M.M. Socioeconomic factors in tuberculosis. N. Engl. J. Med. 1981; 304: 431-432.

14. Rydzewska A., Wieczorek D., Król I., Lipińska M. Czynniki społeczno-bytowe w ocenie zachorowania na gruźlicę płuc w Kaliszu w latach 1991-2000. Wiad. Lek. 2006; 59: 492-496.

15. Błędowski J. Szczegółowe badania nad gruźlicą płuc w rejonie Lublina w latach 1988-1992. Praca doktorska. Instytut Medycyn Wsi. Lublin 1993.

16. Klepacki M. Wyniki leczenia gruźlicy płuc a warunki życiowe chorych. Pneumonol. Alergol. Pol. 1984: 52: 513-517.

17. Karpińska-Jazdon L., Gałęcki J., Ruszczak A. Epidemiologia gruźlicy układu oddechowego wśród osób bezdomnych w Poznaniu. Pneumonol. Alergol. Pol. 2006: 74: 149-152.

18. Miller M., Mastalerz J., Szczuka I., Piasecki Z., Zielińska B. Wpływ wybranych czynników socjalno-bytowych na gruźlicę w Polsce. Pneumonol. Alergol. Pol. 1996; 64: 253-260.
19. Jagodziński J., Zielonka T.M., Błachnio M. Status społeczno-ekonomiczny i czas trwania objawów u mężczyzn chorych na gruźlicę leczonych w Mazowieckim Centrum Leczenia Chorób Płuc i Gruźlicy w Otwocku. Pneumonol. Alergol. Pol. 2012; 80: 533-540.

20. Mysakowska H., Załuska S., Grodzki S., Kucharski R., Pietroń E. Postacie kliniczne gruźlicy płuc u kobiet i mężczyzn ze środowiska wiejskiego i miejskiego. Gruźlica 1959; 27: 1153-1165.

21. Baran Cz., Sieliwończyk P. Społeczne czynniki ryzyka gruźlicy w woj. gdańskim. Ann. Acad. Med. Gedan. 1994; 24: 159-170.

22. Zalc-Świerczewska E., Grzelewska-Rzymowska I. Gruźlica płuc $w$ rodzinach osób chorych na gruźlicę potwierdzoną bakteriologicznie. Pneumonol. Alergol. Pol. 1999: 67: 367-370.

23. Buraczewski O., Rudziński H., Szaciłło Z. Chorobowość i nowo wykryte przypadki gruźlicy (zapadalność) na podstawie statystyki poradni przeciwgruźliczych w roku 1957. Gruźlica 1959; 27: 665-682.

24. Korzeniewska-Koseła M. Gruźlica w Polsce — czynniki sukcesu leczenia. Pneumonol. Alergol. Pol. 2007; 75 (supl. 2): 1-104.

25. Tekkel M., Rahu M., Loit H.M., Baburin A. Risk factors for pulmonary tuberculosis in Estonia. Int. J. Tuberc. Lung Dis. 2002; 6: 887-894.

26. Coker R., McKee M., Atun R. i wsp. Risk factors for pulmonary tuberculosis in Russia: case-control study. BMJ 2006; 332: 85-87.

27. Nájera-Ortiz J.C., Sánchez-Pérez H.J., Ochoa-Díaz H. i wsp. Demographic, health services and socio-economic factors associated with pulmonary tuberculosis mortality in Los Altos region of Chiapas, Mexico. Int. J. Epidemiol. 2008; 37: 786-795.

28. Pakasi T.A., Karyadi E., Dolmans W.M., van der Meer J.W., van der Velden K. Malnutrition and socio-demographic factors associated with pulmonary tuberculosis in Timor and Rote Islands, Indonesia. Int. J. Tuberc. Lung Dis. 2009; 13: 755-759.

29. Cantwell M.F., Mckenna M.T., McCray M., Onorato I.M. Tuberculosis and race/ethnicity in the United States impact of socioeconomic status. Am. J. Respir. Crit. Care Med. 1997; 157: 1016-1020.

30. Neyrolles O., Quintana-Murci L. Sexual inequality in tuberculosis. PloS One. 2010; 5: e10043. doi: 10.1371/journal. pone.0010043.

31. Borgdorff M.W., Nagelkerke N.J., Dye C., Nunn P. Gender and tuberculosis: a comparison of prevalence surveys with notification data to explore sex differences in case detection. Int. J. Tuberc. Lung Dis. 2000; 4: 123-132.

32. Gourdy P., Araujo L.M., Zhu R. i wsp. Relevance of sexual dimorphism to regulatory T cells: estradiol promotes IFN-gamma production by invariant natural killer T cells. Blood 2005; 105: $2415-2420$.

33. Falagas M.E., Mourtzoukou E.G., Vardakas K.Z. Sex differences in the incidence and severity of respiratory tract infections. Respir. Med. 2007; 101: 1845-1863.

34. Carratala J., Gudiol F., Pallares R. i wsp. Risk factors for nosocomial Legionella pneumophila pneumonia. Am. J. Respir. Crit. Care Med. 1994; 149: 625-629. 